\title{
Cuilture as an Antecedent to Organizational Performance: A Case of Private Universities in Kenya
}

\author{
Bonn Odera Jonyo \\ DBA. USIU, Africa \\ Caren Ouma Ph.D. Associate Professor \\ Zachary Mosoti Ph.D. Associate Professor \\ USIU, Africa
}

Doi: 10.19044/ejes.v6no1a7

URL:http://dx.doi.org/10.19044/ejes.v6no1a7

\begin{abstract}
With the recent declaration of Sustainable Development Goals to 2030 at the United Nations, all nations are focused on ensuring inclusive and equitable quality education and promote life-long learning opportunities for all. In this respect, a well-structured and holistic curriculum is an important first entry point in guiding learning processes embedded in a strong culture. The purpose of the study was to examine how sustaining culture affect organizational performance in private universities in Kenya. This was a correlational study which adopted a positivist philosophy. The study population comprised of all the 17 private universities in Kenya accredited by Commission of University Education. The unit of analysis was the board of directors, vice chancellors, heads of departments (finance, sports, human resource, research, quality assurance) and academic deans (business school) which was 136. A census technique was used in the study with frequency distributions, percentages and means for descriptive statistical analysis while correlations and regression analyses were used for inferential statistics. The study found that, organizational culture explained a significant proportion of variance in organizational performance, $\mathrm{R}^{2}=.461$. Organizational culture significantly predicted organizational performance, $\beta=.679$, t $(120)=10.090$, $\mathrm{p}=.000$. This finding implied rejection of the null hypothesis since the $\mathrm{p}$ value was less than $<.05$ set by the study.
\end{abstract}

Keywords: Effective culture, antecedent, organization culture, strategic leadership, performance.

\section{Introduction}

In the age of globalization, the knowledge economy discourse has become a way to characterize the new relationship between higher education, 
the state and society, and the economy. Institutions of higher education core functions consist of teaching, research and community extension service (UNESCO,2010) which are grounded in very strong cultures of the founders.

Organizational culture is a multifaceted set of philosophies, symbols, and core values shared throughout the firm. Culture provides the context within which strategies are formulated and implemented. Organizational culture is concerned with decisions, actions, communication patterns, and communication networks. Because they are formed over the life of a company, culture reflects what the firm has learned across time through its responses to the continuous challenges of survival and growth. In the global economy, strategic leaders capable of learning how to shape a firm's culture in competitively relevant ways will become a valued source of competitive advantage (Ireland \& Hitt, 2016).

Strategic leadership designates the use of the strategy process as a systematic method of decision making that integrates reciprocal leadership into its concepts and practices. Morrill, (2010) investigated how strategic leadership is applied in the American universities by situating the phenomenon within the dimensions of human moral agency and identity. This marks a new epoch of contemporary study on strategic leadership in higher education. In most universities and colleges, emphasis is put mainly on management but not on leadership which is understood as a process that involves setting directions, motivating others and coping with change.

When the board of directors and the leadership in the organization are involved in shaping an organization's direction, the organization generally improves its performance critical element of strategic leadership and organizational performance, and the ability of leadership to manage and utilize the organization's resource portfolio. This includes integrating resources to create capabilities and leveraging those capabilities through strategies to build competitive advantages and high performance (Ireland \& Hitt, 2013). This study endeavors to examine an effective culture as a construct of strategic leadership affect organization performance in private universities in Kenya.

\section{Research Problem}

UNESCO, (2014) report, indicates that the past one decade, 57\% of youthful population from developing countries pursue university education outside their home countries This implies that there is a high demand for quality university education among the youth in developing countries. The high demand for university education has presented private universities with defective organization culture leading to ineffectiveness in university systems and proseses. All these have a challenge to high performance of education outcomes as set by the Commission of University Education in Kenya (MoEST, 2015). Consequently, this attracted poor ranking in the world 
webometrics of universities (2016). Gaps have been identified in policy adherence and enforcement areas necessary, therefore sought to examine the effect of sustaining culture organizational performance with reference to private universities in Kenya.

\section{Literature Review}

The theoretical orientation for this study was anchored on the strategic leadership theory as advanced by Ireland and Hitt, (2013) which asserts that companies are reflections of their top managers and, the chief executive officers, and that the specific knowledge, experience, values and preferences of top managers are reflected not only in their decisions, but in their assessments of decision environments. Consequently, the significant choice options available to the CEO as the firm's key strategic leader, who often work as a 'Lone Ranger' in the organization primarily using top-down directives (Cannella \& Monroe, 1997). As a principle when these choices resulted in financial success for the company, the key strategic leader was recognized widely as the "corporate Hercules" (Senge, 2014).

\section{Conceptual Framework}

The conceptual framework for this study was derived from the strategic leadership theory (Ireland \& Hitt, 2013).

Independent Variables

Moderating Variable

\section{Organizational Culture}

- Productivity Standards

- Rewards to Employees

- Motivations

\section{Policy and Regulation \\ - Complain Policy \\ - Quality Assurance Policy \\ - Resource Maintenance Policy}

Source: Researcher
Dependent Variable

Organizational

\section{Performance}

Financial Perspective

- Cost Reduction

- Outstanding enrolment

- Profits/Surplus

Learning and Growth

- Initiative/Innovation

- Internal Business Process

- Operations Timeliness

The study conceptualized a framework consisting of the dependent and independent variables to achieve the research objective (examining the effect of sustaining an effective cultre on organizational performance in private 
universities in Kenya). The following null hypothesis derived from the research question guided the study:

$\boldsymbol{H}_{01}$ How does Sustaining an effective culture affect organizational performance in private universities in Kenya

The designing of the universities' strategic direction assists to direct organizational processes in terms of strategy implementation and therefore serves to communicate an effective culture in strategic objectives and the formulation of the strategic plan (Ireland, et al., 2016).

\section{Organizational Culture}

According to Ireland et al. (2016), organizational culture is a complex set of philosophies, signs and core values that are shared within the organization and that determines how its business is conducted. It is therefore critical for strategic leaders to comprehend that, whether the firm's culture is functional or dysfunctional, their effectiveness is influenced by that culture. The work of strategic leaders and organizational culture has a reciprocal relationship that culture shapes the outcomes of their leadership while their leadership helps shape an ever-evolving organizational culture (Stevens, 2008). Therefore, strategic leaders are also affected by the organizational culture and their work in the organizations.

Culture determines how the organization conducts its business and it helps regulate and control employees' behavior and perception, it is source of competitive advantage depending on its proactivity (Gupta, 2013). According to Laforet (2016), some organizational cultures operate in a heavy-handed and competitive manner with little room for deviations and little tolerance with the expression of discontent. It is critical to remember that cultural norms can transmit effective and healthy patterns of behaviour. Drucker (1997), argues that every organization has a culture that supports to profile and define the context in which an individual's behaviour is perceived and evaluated.

The prominence a leader gives is influenced by the organization's culture and the formal and informal reward systems that reinforce that culture. The most powerful factors are delicate and difficult to observe unless one is part of the system. The dominant rules that drive and enhance leader behaviour are often the unwritten and unspoken threads that are interfaced into the fabric of day-to-day life. Employees come to know these subtleties by how they are rewarded or punished. The rewards and punishments are themselves often subtle and shape the behaviour and are most powerful when they are outside the leadership's awareness (Drucker, 1997).

According to Daft (2015), organizational culture is at times referred to as corporate culture and can largely be classified into four types: adaptability, clan, mission, and bureaucratic. The adaptability culture is characterized by strategic focus on the external environment through flexibility and change to 
meet customer needs. The focus of a mission culture is on outlining the organization's vision, purpose and goals. The bureaucratic culture has an internal focus and is thus best suited for stable environments. Lastly, the primary focus of the clan culture is on employee involvement and participation. Daft (2015), further submits that the appropriate type of culture for any organization embodies those characteristics which support the organization to be effective within the environment it operates. This agrees with Asby's requisite variety law which states that only variety can absorb variety (Schwaninger, 2009). Since most of today's organizations operate in fast-changing environments, organizational adaptability is considered key to high performance system design.

Laforet (2016), advances three dimensions of organizational culture to consider, that is: consumer orientation, service quality, and informality and innovation which are significantly associated with marketing effectiveness. The findings of studies by Heskett, et.al. (1994), are consistent with the results on successful service organizations, which established relationships between profitability, customer loyalty and employee satisfaction, loyalty, and productivity. More specifically, the study suggests that service organizations that value customer satisfaction by providing quality service and innovative ideas, and that value free communication within the organization, demonstrate more marketing effectiveness than those which do not treasure these values (Kraus, Craig, Dibrell \& Stefan, 2012). These aspects are concerned with people and quality of service subsequently. Hence, top management in service companies should try to build up in their firms a team spirit characterized by a preoccupation with pride in the quality of the service provided with a focus to put heavy emphasis in motivating the individual employee to bring this into effect.

De Sivatte, Gordon, Rojo and Olmos (2015), argues that while organizations that share the three sets of values are found to have a higher level of marketing effectiveness, it was the first dimension of marketing effectiveness, marketing efficiency that is strongly associated with business profitability. It supports the assertion that service organizations that demonstrate superior profitability are also those that achieve higher marketing efficiency, and these companies are characterized by an organizational culture with identifiable corporate values that treasures consumer orientation, provision of quality services, free communication and innovation. Also, one aspect of organizational values puts emphasis on service quality which has a positive impact on profitability directly through itself and indirectly through its effect on effectiveness.

Previously, scholars have suggested that organizational culture is a determinant of private organization innovativeness. They have also claimed that private firms profit from their organizational culture, which tends to have 
fewer issues with principle agent problems and reduced reliance on formal controls and coordination. These traits make private organizations a more efficient innovator taking cognizance of the effects of organizational innovation (Kraus et al. 2012). However, there has been little research that examines the influence of organizational culture on the innovation process of private organizations, and the issue to grapple with is which family cultures would bring about innovation and which would hinder it. The study focused on which type of organizational culture lead to high innovation performance in private enterprises.

Craig et al. (2014), suggests that pro-activeness influences private firms' innovation output and from the study the findings show that an externally oriented family business culture has a positive effect on private firms' innovation performance, an externally oriented organizational culture refers to market orientation, firm's adaptability and interaction with the external environment. In the case of family firms, this includes interacting with customers, competitors, suppliers, stakeholders and non-family employees. Furthermore, the findings show that an open private business culture has a positive effect on private firms' innovation performance (Laforet, 2016). In contrast, a paternalistic and a founder culture do not have a positive effect on private firms' innovation performance. This finding tends to concur with research which suggests the later-generation CEO influence higher innovation output than the founder CEO (Duran, Kammerlander, van Essen, \& Zellweger, 2015). A paternalistic culture is synonymous with a closed culture, with this culture the firm is not able to foster change and generates value over time (Chirico \& Nordqvist, 2010), also one of the conditions for innovation. The founder culture would increase the private firm inward focus culture (Zahra et. al. 2004) and impedes innovation.

The findings also show that a flexible and a long-term oriented family business culture have a positive effect on family firms' innovation performance. A flexible organizational culture emphasizes teamwork, including explicit practices, employee empowerment and change, through commitment to training and utilization of technology. Generally, literature suggests that private firms are not very flexible, as by their nature they are often very attached to tradition, culture and family values. There may be resistance to new ideas and change, and they may prefer to work within the family guidelines instead (Alderfer, 1988).

Kellermanns and Eddleston (2006), submits that private firms can increase corporate entrepreneurship, including innovation, by pursuing organizational change and exploiting opportunities as well as by recognizing technological opportunities. Although change could be a threat to private firms' status quo, it is a necessary condition for organizational innovation performance in private firms. Studies show that empowering employees and 
connecting with others or involving others including, non-family employees positively affect organizational innovation performance in private SMEs. This is the same with non-family firms where past studies also show that employee empowerment increases SMEs’ ability to innovate (Çakar \& Ertürk, 2010).

In terms of practical implications, family organizations need to be mindful of their own cultures and practices and try to adopt or be aware of those that can contribute positively to their innovation success or performance. Similarly, this research has highlighted that SMEs are highly innovative, but more need to be done to enhance their entrepreneurial attitudes and behaviors (Laforet, 2016). Generally, it is difficult to measure organizational culture through a quantitative approach as it is instilled in individual's beliefs, values and perceptions, a qualitative research methodology would have complemented the quantitative approach used in this study. The study has not examined the artefacts and norms of organizational culture. Likewise, it did not incorporate other organizational contingencies of family firms like the role of family CEO and family chair. Thus, these will be the subject of future research. Future research could distinguish between types of innovation and types of organizational culture as well as incorporating other organizational contingencies of family firms, focusing deeply on the generational effects of organizational culture that may affect family firms and using a qualitative research methodology. Finally, this research could also be replicated in nonindividualistic non-Western countries to ascertain where organizational cultural values differ especially in institutions of higher learning. Culture is a very important component in an organizational structure because it is the glue which holds the firm together.

\section{Organizational Performance}

According to Richard et al., (2013) the actual outcomes and results of an organization as measured against its intended goals and objectives constitutes organizational performance. It comprises three specific areas of the firm outcomes: financial performance such as profits, return on assets, return on investment; product market performance such as sales, market share, and shareholder return such as total shareholder return, economic value added. Armstrong (2017) defines performance as the record of outcomes produced on a specified job function or activity during a specified period. Therefore, performance is measured in terms of output and outcome, profit, internal processes and procedures, organizational structures, employee attitudes, and organizational responsiveness to the environment among others (William 2002).

In recent years, many organizations have attempted to manage organizational performance using the balanced scorecard methodology (Kaplan \& Norton, 2001) where performance is tracked and measured in 
multiple dimensions such as: financial performance (e.g. shareholder return), customer service, social responsibility (e.g. corporate citizenship, community outreach) and employee stewardship. Balanced scorecard also identifies the measures used to monitor, review and assess performance (Armstrong, 2017). For an organization to succeed, this is contingent on the capability of its top managers, leaders and a sustainable organizational culture created by those leaders. The belief and value systems created by the leaders always influence its performance (Soebbing et al., 2015). According to Ssekakubo et al., (2015), leadership competencies have a direct positive effect and always improves employee performance. This is further affirmed by researchers who have focused on the relationship between the competencies of leaders and how their organizations perform in the world economies.

\section{Policy and Regulation}

The Ministry of Education Science and Technology (MoEST) has developed policy and legislative framework for education and training to realign the human capital development needs of the country to the Constitution and the Kenya Vision 2030. The Commission for University Education (CUE) is the main regulator of university education in Kenya. The policy on education and training therefore envisage a curriculum that successively develops the knowledge, skills, competencies, as well as lifelong learning dispositions of its citizens to meet the human capital needs of the country. Besides ensuring that learners are getting quality education and training, the Commission will consider such issues as the effectiveness of Government education policy implementation, strategic planning, resource mobilization and the management of resources by Ministries and institutions concerned with education and their management bodies. The goal is to develop a repertoire of skills and competencies necessary to achieve the objectives and goals embodied in the Constitution, 2010 and Kenya Vision 2030. The policy framework on education and training also envisages an education curriculum with parallel and complimentary tiers: academic, vocational and technical curricular. The Government will accordingly introduce a multi-track system to take care of the learning needs of all these categories of education and provide a window for the progression to higher education through any of the three tiers (MoEST, 2008).

\section{Methodology}

Positivism research philosophy was adopted in the study premised on measurable observations that lead themselves to statistical analysis. The use of appropriate research philosophy helps researchers to eliminate unrelated factors from the research (Cooper \& Schindler, 2014). 
The correlational design was used for this study because it has a wide range of variables and their interrelatedness (Creswell, 2014). The design was deemed suitable because this study focused on examining the effect culture on organizational performance. The target population for this study included all the 17-chartered private universities with the Commission of University Education (CUE, 2016) particularly the board members, vice chancellors, academic deans (business schools) and heads of departments (finance, quality assurance, research, security, human resource and sports) as the unit of analysis with a total of 136 respondents.

The study adopted a census study in line with Israel (2009) and Rao (2015) recommendations that sample sizes of less than 200 are studied to cater for any non-response that may be encountered in the study. The estimated sample size of 136 respondents was distributed proportionate to the size of the population.

The questionnaire was the main tool for data collection, preferred because it possesses a high rate of response and that the respondents can respond to the questions simultaneously hence saving time. Reliability was tested using the Cronbach's alpha. This is a measure of internal consistency that is, how closely related a set of items are as a group and it is a measure of scale reliability. A reliability coefficient of at least 0.7 Cronbach Alpha was accepted in the study. In this study, the validity of the study was ascertained by the subject experts. The analysis was done by use of; descriptive statistics to present data into charts and tables with frequency distribution and percentages as well as means and standard deviations while; inferential statistics tested the hypothesised relationships between the independent and dependent variables which included correlation and regression analyses.

Normality test was done in the study to determine if the data set is wellmodelled by a normal distribution. In this study, normality tests were done using kurtosis and skewness. Skewness and kurtosis values that range from +/-3 (SE) are generally considered normal (Onwuegbuzie \& Daniel, 2002). Multicollinearity was done in the study using the variance inflation factors (VIF) for each variable using traditional criteria employed in the study. Linearity - The study conducted linearity test to determine whether the relationship between each of the independent variable and dependent variable was linear or not. The study findings had the homoscedasticity test evaluated for pairs of variables using the Levene statistic for the test of homogeneity of variances.

\section{Findings and Results}

The researcher sought to examine the effect of organization culture on performance in private universities in Kenya. Data was analyzed at two levels where the first level entailed determining organizational culture. The second 
part involved analyzing results on the effect of organizational culture on organizational performance.

\section{Factor Analysis Results on Organizational Culture}

Factor analysis was conducted in the study to describe variability among items of organizational culture. Organizational culture construct was measured using ten (10) items thereby the construct was factor analyzed to come up with an appropriate measure. The study found that organizational culture had KMO value of 0.828 and Bartlett's test, $x 2(45, N=124)=390.136$, $p=.000$. This was meritorious; therefore, the adequacy of the sample was acceptable. Therefore, sampling was adequate for organizational culture as given by the Kaiser-Meyer-Olkin Measure of Sampling Adequacy value.

\section{KMO and Bartlett's Test for Organizational Culture}

The study also carried out the Eigen values for the factors under organizational culture. According to the findings, the first factor accounts for $41.704 \%$ of the variance in organizational culture while the second factor accounts for $14.228 \%$ of the variance in organizational culture.

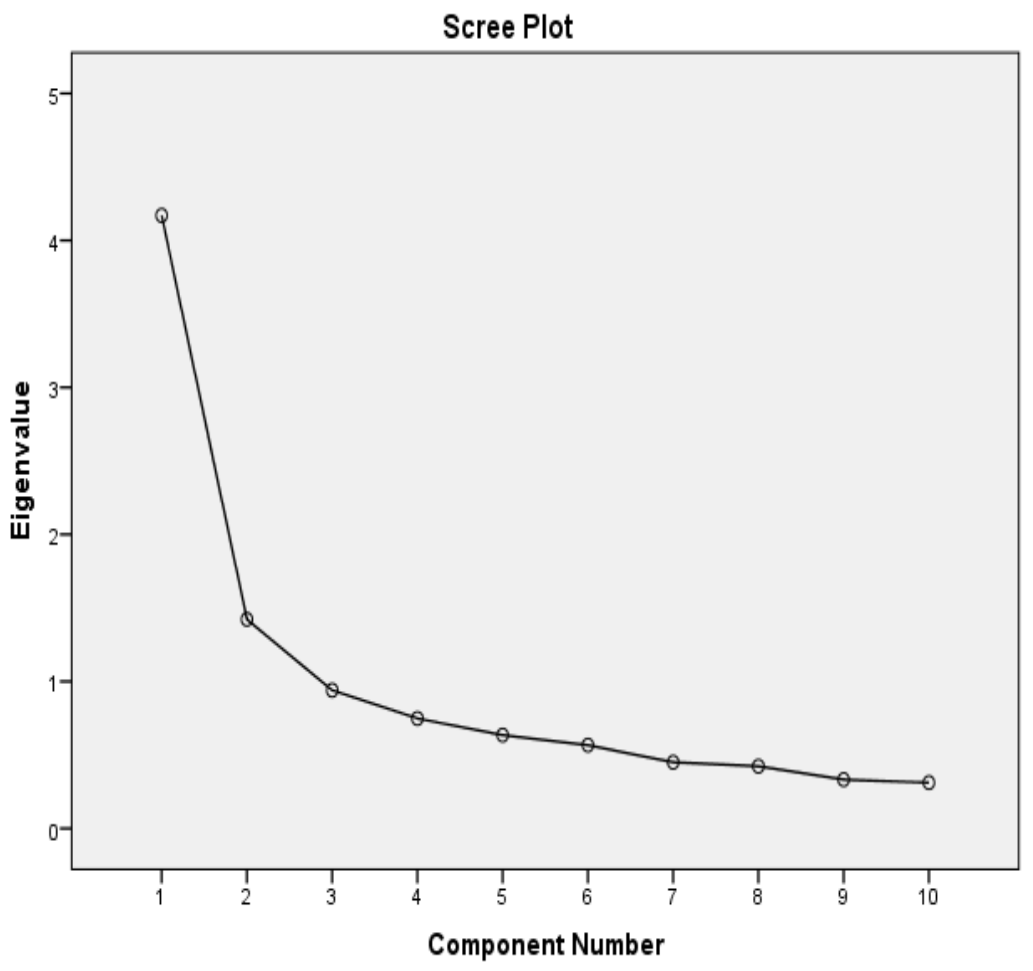

Figure 1 Scree Plot for Organizational Culture 
The results for scree plot indicated that two components had Eigen value that was greater than one. This finding corroborates total variance explained results for Organizational culture.

The study sought to determine the factor loadings for organizational culture. The findings obtained indicated that "The university encourages us to be honest and have integrity as we carry out our duties" had the highest factor loading in the first component with 0.773 while "The university uses retraining to deal with employees who are no longer productive" had the highest factor loading of 0.732 in the second component.

\section{Frequency Distribution on Organizational Culture}

The findings indicated that $32.5 \%$ of the respondents agreed that the university uses re-training to deal with employees who are no longer productive, $29.2 \%$ neither agreed nor disagreed, $16.7 \%$ disagreed, $15.8 \%$ strongly disagreed and 5.8\% strongly agreed. Some respondents (32.5\%) neither agreed nor disagreed that the university uses demotions, early retirements, and transfer, on non-performing employees, $25.8 \%$ disagreed, $20 \%$ agreed, $15 \%$ strongly disagreed and $6.7 \%$ strongly agreed. Some respondents $(33.1 \%)$ agreed that rewards such as salary increases, bonuses and promotions are pegged to targets met, which ensures consistency in the overall growth of the university, $26.4 \%$ disagreed, $19 \%$ neither agreed nor disagreed, $11.6 \%$ strongly disagreed and $9.9 \%$ strongly agreed. Some respondents $(37.2 \%)$ of the respondents agreed that the leaders in the university strive to motivate the employees to give their best, hence the consistence growth over the years, $23.1 \%$ neither agreed nor disagreed, $19 \%$ disagreed, $15.9 \%$ strongly agreed while $5.8 \%$ strongly disagreed.

The findings also indicated that $38.1 \%$ of the respondents agreed that the employees in the university strive to give their best, $28.8 \%$ neither agreed nor disagreed, $24.6 \%$ strongly agreed, $7.6 \%$ disagreed and $0.8 \%$ strongly disagreed. Some respondents (48.3\%) agreed that the university's culture has influenced its student numerical growth in the last 5 years, $22.5 \%$ strongly agreed, $21.7 \%$ neither agreed nor disagreed, $5.8 \%$ disagreed and $1.7 \%$ strongly disagreed. Some respondents (49.6\%) agreed that the university cultivates an environment of trust and teamwork, $21.5 \%$ strongly agreed, $19.8 \%$ neither agreed nor disagreed, $7.4 \%$ disagreed and $1.7 \%$ strongly disagreed. Some respondents $(37.2 \%)$ agreed that the university encourages us to be honest and have integrity as we carry out our duties, $34.7 \%$ strongly agreed, $19 \%$ neither agreed nor disagreed, $7.4 \%$ disagreed and $1.7 \%$ strongly disagreed. Further, $43.8 \%$ of the respondents strongly disagreed that the university expects me to treat organizational documents as confidential, $43 \%$ agreed, $6.6 \%$ neither agreed nor disagreed, $5 \%$ disagreed and $1.7 \%$ strongly disagreed. In addition, $47.9 \%$ of the respondents agreed that the university ensures that all rules and 
policies are adhered to, $33.1 \%$ strongly agreed, $11.6 \%$ neither agreed nor disagreed, $5.8 \%$ disagreed and $1.7 \%$ strongly disagreed.

\section{Mean and Standard Deviation for Organizational Culture}

The study also sought to analyze the views of respondents on organizational culture using a table of means and standard deviations. A Likert scale data was collected rating the views in a scale. The mean results are therefore given on a scale interval where a mean value of 1 is an indication of strongly disagree; 2 is disagree; 3 is neutral, 4 is agree and a mean value of 5 is an indication of strongly agree.

According to the findings, the respondents strongly agreed to the following statements: Rewards such as salary increases, bonuses and promotions are pegged to targets met, which ensures consistency in the overall growth of the university duties $(M=3.03, S D=1.211)$; the leaders in the university strive to motivate the employees to give their best, hence the consistence growth over the years duties $(M=3.36, S D=1 . .125)$; the employees in the university strive to give their best duties $(M=3.78, S D=$ $0.935)$; the university's culture has influenced its student numerical growth in the last 5 years duties $(M=3.84, S D=0.898)$; The university cultivates an environment of trust and teamwork duties $(M=3.82, S D=0.913)$; and the university encourages us to be honest and have integrity as we carry out our duties $(M=3.96, S D=0.995)$.

The respondents strongly agreed that the university expects me to treat organizational documents as confidential $(M=4.22, S D=0.899)$ and the university ensures that all rules and policies are adhered to $(M=4.05, S D=$ 0.912). The respondents however neither agreed nor disagreed that the university uses re-training to deal with employees who are no longer productive $(M=2.96, S D=1.169)$ and the university uses demotions, early retirements, and transfer, on non-performing employees $(M=2.78, S D=$ 1.133).

\section{Correlation between Organizational Culture and Performance}

The study correlated organizational culture and performance and found that all the items of organizational culture were positively and significantly related with organizational performance. The university uses re-training to deal with employees who are no longer productive and organization performance were moderately correlated, $r(120)=.361, p<.000$. The university uses demotions, early retirements, and transfer, on non-performing employees and organization performance were correlated, $r(120)=.231, p<$ .011 . Rewards such as salary increases, bonuses and promotions are pegged to targets met, which ensures consistency in the overall growth of the university and organization performance were moderately correlated, $r(121)=.484, p<$ 
.000 . The leaders in the university strive to motivate the employees to give their best, hence the consistence growth over the years and organization performance were moderately correlated, $r(121)=.553, p<.000$. The employees in the university strive to give their best and organization performance were moderately correlated, $r(118)=.344, p<.000$. The university's culture has influenced its student numerical growth in the last 5 years and organization performance were moderately correlated, $r(120)=$ $.534, p<.000$. The university cultivates an environment of trust and teamwork and organization performance were moderately correlated, $r(121)=.536, p<$ .000 . The university encourages us to be honest and have integrity as we carry out our duties and organization performance were moderately correlated, $r(121)=.447, p<.000$. The university expects me to treat organizational documents as confidential and organization performance were moderately correlated, $r(121)=.409, p<.000$. The university ensures that all rules and policies are adhered to and organization performance were moderately correlated, $r(121)=.518, p<.000$.

\section{Correlation Analysis on Organizational Culture Index}

The study sought to determine the relationship between organizational culture index and performance using correlation analysis and found that the two variables were moderately correlated $r(121)=.679, p=.000$.

\section{Chi Square Test on Organizational Culture}

Chi square test was used to test the strength of association between organizational culture and organizational performance. The study found a strong association between organizational culture

\section{One Way ANOVA on Organizational Culture}

A one-way ANOVA was carried out to establish if there was significant difference between the mean of organizational culture with number of years in leadership position at the private universities as well as the current leadership position. The tests established that the mean for organizational culture were the same for the number of years in leadership position $F(2,108)$ $=0.066, p=0.936$. The study also found out that the mean for organizational culture were the same for the current leadership position, $F(3,115)=10.976$, $p=0.407$.

\section{Assumptions for Regression on Organizational Culture}

The study conducted the assumptions of regression to determine whether regression analysis was suitable in the study or not. The diagnostic tests conducted in the study included normality, linearity, homoscedasticity and multicollinearity tests. 


\section{Normality Test for Organizational Culture}

The study checked the normality of the data set by looking at descriptive values of skewness and kurtosis. The skewness values obtained in the study indicated that the scores are skewed as many are negatively skewed and not that much closer to zero. The values range from -2 to +1 hence no skewness problems in the study. The kurtosis values also fall within the range of -2 to +3 , and therefore do not display excessive kurtosis as well. These results suggested that the normality assumption is not violated in the study.

\section{Linearity Test for Organizational Culture}

The study conducted linearity test to determine whether the relationship between organizational culture and organizational performance was linear or not. According to the results shown in Table 11, the significant deviation from linearity is 0.445 which is greater than 0.05 implying than there is a linear relationship between organizational culture and organizational performance.

\section{Homoscedascity Test for Organizational Culture}

The study findings had the homoscedasticity test evaluated for pairs of variables using the Levene statistic for the test of homogeneity of variances. The results are then given as shown in Table 12. From the study findings of test for homogeneity, the probability associated with the Levene Statistic $(<0.071)$ is more than the level of significance $(0.05)$ testing at 1 -tail test $5 \%$ significance level, the researcher concludes that the variance is homogeneous for organizational culture.

\section{Homoscedasticity Test for Organizational Culture}

\begin{tabular}{|l|l|l|l|}
\hline Levene Statistic & df1 & df2 & Sig. \\
\hline 2.031 & 21 & 93 & .071 \\
\hline
\end{tabular}

\section{Multicollinearity Test for Organizational Culture}

Multicollinearity is a state of very high intercorrelations or interassociations among the independent variables. Multicollinearity in the study was checked using the variance inflation factors (VIF). The VIF values of between 1 and 10 show that multicollinearity is not problematic in the study while VIF values of less than 1 and more than 10 indicate multicollinearity issues in the study. The findings obtained indicated that the VIF value for organizational culture is 3.120 which is between 1 and 10 and therefore multicollinearity was not problematic in the study 


\section{Multicollinearity Test for Organizational Culture}

\begin{tabular}{|l|l|l|l|}
\hline \multirow{2}{*}{ Model } & \multicolumn{3}{|l|}{ Collinearity Statistics } \\
\cline { 3 - 4 } \multicolumn{1}{|l}{1} & Tolerance & VIF \\
\hline \multirow{4}{*}{1} & Organization's Mission or Vision & 441 & 2.269 \\
\cline { 2 - 4 } & Human Capital Development & 240 & 4.173 \\
\cline { 2 - 4 } & Organizational Culture & .321 & 3.120 \\
\cline { 2 - 4 } & Ethical Values & 248 & 4.037 \\
\cline { 2 - 4 } & Strategic and Financial Controls & .257 & 3.898 \\
\hline
\end{tabular}

a. Dependent Variable: Organizational Performance

\section{Hypothesis Testing for Organizational Culture.}

Based on linear regression model, the study sought to establish the effect of organizational culture on organizational performance. The following hypothesis was therefore tested:

$H_{0}$ : Organizational culture does not affect the organizational performance in private universities in Kenya.

$H_{1}$ : Organizational culture affects the organizational performance in private universities in Kenya.

The study found that organizational culture explained a significant proportion of variance in organizational performance, $\mathrm{R}^{2}=.461$. This implies that $46.1 \%$ of the proportion in organizational performance can be explained by organizational culture in private universities in Kenya. Other factors not covered by this study therefore contribute to $53.9 \%$.

Model Summary for Organizational Culture

\begin{tabular}{|l|l|l|l|l|}
\hline Model & R & R Square & Adjusted R Square & $\begin{array}{l}\text { Std. Error of the } \\
\text { Estimate }\end{array}$ \\
\hline 1 & $.679^{\mathrm{a}}$ & .461 & .457 & .54537 \\
\hline
\end{tabular}

a. Predictors: (Constant), Organizational Culture

The findings indicated that the significance value in testing the reliability of the model for the relationship between organizational culture and organizational performance was $F(1,119)=101.815, p=0.00$. Therefore, the model is statistically significant in predicting the relationship between organizational culture and organizational performance

\section{ANOVA for Organizational Culture}

\begin{tabular}{|l|l|l|l|l|l|l|}
\hline \multicolumn{2}{|l}{ Model } & Sum of Squares & df & Mean Square & F & Sig. \\
\hline \multirow{4}{*}{1} & Regression & 30.282 & 1 & 30.282 & 101.815 & $.000^{\mathrm{b}}$ \\
\cline { 2 - 8 } & Residual & 35.394 & 119 & .297 & & \\
\cline { 2 - 8 } & Total & 65.676 & 120 & & & \\
\hline
\end{tabular}

a. Dependent Variable: Organizational Performance

b. Predictors: (Constant), Organizational Culture 
The study found that organizational culture significantly predicted organizational performance, $\beta=.679, t(120)=10.090, p=.000$. This finding implied rejection of the null hypothesis since the $\mathrm{p}$ value was less than $<.05$ set by the study. The study therefore concluded that organizational culture significantly influences organizational performance in private universities in Kenya.

\section{Regression Coefficients for Organizational Culture}

\begin{tabular}{|c|c|c|c|c|c|c|}
\hline \multirow{2}{*}{\multicolumn{2}{|c|}{ Model }} & \multicolumn{2}{|c|}{$\begin{array}{l}\text { Unstandardized } \\
\text { Coefficients }\end{array}$} & \multirow{2}{*}{\begin{tabular}{|l|}
$\begin{array}{l}\text { Standardized } \\
\text { Coefficients }\end{array}$ \\
Beta \\
\end{tabular}} & \multirow[t]{2}{*}{ t } & \multirow[t]{2}{*}{ Sig. } \\
\hline & & B & Std. Error & & & \\
\hline \multirow[b]{2}{*}{1} & (Constant) & 1.115 & .273 & & 4.081 & .000 \\
\hline & $\begin{array}{l}\text { Organizational } \\
\text { Culture }\end{array}$ & .757 & .075 & 679 & 10.090 & .000 \\
\hline
\end{tabular}

a. Dependent Variable: Organizational Performance

The findings obtained in the study implied that for every one-unit change in organizational culture, organizational performance increases by 0.757 hence implying a positive impact of organizational culture on organizational performance.

\section{Conclusion}

The study found that, organizational culture explained a significant proportion of variance in organizational performance, $\mathrm{R}^{2}=.461$. This implies that $46.1 \%$ of the proportion in organizational performance can be explained by organizational culture in private universities in Kenya. Organizational culture significantly predicted organizational performance, $\beta=.679, t(120)=$ $10.090, p=.000$. This finding implied rejection of the null hypothesis since the $\mathrm{p}$ value was less than $<.05$ set by the study.

The study determined that the universities did not use re-training to deal with employees who are no longer productive and did not use demotions, early retirements, and transfer, on non-performing employees. In addition, rewards such as salary increases, bonuses and promotions were not pegged to targets met, and therefore did not ensure consistency in the overall growth of the university. Therefore, the study recommends that universities need to retrain their employees who are no longer productive, give rewards to best performing employees and also can use transfers, early retirements and demotions for the under-performing employees in order to foster their performance.

\section{Recommendations}

The study recommends that the universities' budgetary and planning priorities need to be aligned to the sustaining cultures of their founders to align 
itself to the emerging dynamics in higher education landscape to improve performance.

\section{References:}

1. Absar, M. N., Nimalathasan, B., \& Jilani, M. M. A. K. (2010). Impact of HR practices on organizational performance in Bangladesh. International Journal of Business Insights and Transformation, 3(2), 15-19.

2. Academic Ranking of World Universities (2016). Institute of Higher Education, Shanghai Jiao Tong University.

3. Armstrong, M. (2017). Armstrong's Handbook of Performance Management: An Evidence-Based Guide to Delivering High Performance, London. 6th. Kogan PAGE.

4. Cannella, A. A. Jr., \& Monroe, M. J. (1997). Contrasting Perspectives on Strategic Leaders: Toward a More Realistic View of Top Managers, Journal of Management, 23, 213-237.

5. Cassar, G. (2010). Are individuals entering self-employment overly optimistic? An empirical test of plans and projections on nascent entrepreneur expectations, Strategic Management Journal, 31: 822840.

6. Chirico, F., \& Nordqvist, M. (2010). "Dynamic capabilities and transgenerational value creation in family firms: the role of organizational culture", International Small Business Journal, Vol. 28 No. 5, pp. 487504.

7. Cooper, D., \& Schindlers, P. (2014). Business Research Methods 12th Ed. New York MCGRAW HILL Irwin.

8. Craig, J., Pohjola, M., Kraus, S., \& Jensen, S. (2014). "Exploring Relationships Among Pro-activeness, Risk-Taking And Innovation Output in Family and Non-Family Firms", Creativity and Innovation Management, Vol. 23, No. 2, pp. 199-210.

9. Creswell, J. W. (2014). Designing and Conducting Mixed Methods Research (4ndEd) Thousand Oaks, CA: SAGE.

10. CUE, (2018). The State of University Education in Kenya: Selected Papers from the 1st Biennial Conference Proceedings.

11. Daft, R., (2015). Organization Theory and Design. New York, NY. Barnes \& Noble Booksellers, Inc.122 Fifth Avenue.

12. De Sivatte I., Gordon, R.J., Rojo P., \& Olmos, R. (2015). "The impact of work-life culture on organizational productivity", Personnel Review, Vol. 44 Iss 6 pp. 883 - 905.

13. Drucker, P. F. (1997). The next 20 years, Executive Upside, The future that has already happened. Harvard Business Review, 75(6):22. 
14. Duran, P., Kammerlander, N., van Essen, M., \& Zellweger, T. (2015). "Doing more with less: innovation input and output in family firms", Academy of Management Journal. Vol. 59, No. 4.

15. Gupta, V., \& Singh, S. (2010). Developing a set of high performance $H R M$ practices and exploring its relationship with $O C B$ and organizational justice. In SMA 2010 proceedings (pp. 464-469). Retrieved June 29, 2013, from http://mail.iiml.ac.in/ fpm9013/PaperID232.pdf

16. Ireland, R. D., Hoskisson, R.E., \& Hitt, M. A. (2013). The Management of Strategy Concepts and Cases, $10^{\text {th }}$ ed. Mason, $\mathrm{OH}$ : South-Western CENGAGE Learning.

17. Israel, G. D. (2009). Determining Sample Size. Program Evaluation and Organizational Development, Institute of Food and Agricultural Sciences (IFAS), University of Florida, Gainesville.

18. Kaplan R. S., \& Norton, D.P. (2001). The strategy focused organization, Strategy \& Leadership, 29(3): 41-42; R.S. Kaplan \& D.P Norton, 2000, The Strategy-Focused Organization: How Balanced Scorecard Companies Thrive in the New Business School Press.

19. Kraus, S., Craig, J., Dibrell, C., \& Stefan, M., (2012). "Family firms and entrepreneurship: contradiction or synonym?" Journal of Small Business and Entrepreneurship, Vol. 25 No. 2, pp. 135-139.

20. Laforet, S, (2016). "Effects for Organisational Culture on Organisational Innovation Performance in Family Firms", Journal of Small Business and Enterprise Development, Vol. 23 Iss 2 pp. 379 407.

21. MoEST, (2015). Educational for All Review.

22. Morrill, R. L. (2010). Strategic Leadership, Integrating Strategy and Leadership in Colleges and Universities, NY. Rowman Littlefield Publishers INC.

23. Onwuegbuzie, J.A., Collins, K. M. T., Leech, N. L., Dellinger, A. B., \& Jiao, Q. G. (2015). A meta-framework for conducting mixed research synthesis for stress and coping researchers and beyond. In G.S. Gates, W. H. Gmelch \& M. Wolverton \& K.M.T. Collins, A. J. Onwuegbuzie, \& Q. G. Jiao (Vol. Eds.), toward a broader understanding of stress and coping: Mixed methods approaches (pp.169-211). The Research on stress and coping in Education Series (Vol.). Charlotte, NC: Information Age.

24. Rao, J. N. (2015). Small-Area Estimation. John Wiley \& Sons, Ltd.

25. Richard, A. (2013). Theory Building in Applied Disciplines. San Francisco, CA: Berrett-Koehler Publishers.

26. Senge, P. M. (2014). The dance of change: The challenges to sustaining momentum in a learning organization. Random House LLC 
27. Soebbing, B. P., Wicker, P., \& Weimar, D. (2015). "The impact of leadership changes on expectations of organizational performance", Journal of Sport Management, Vol. 29 No. 5, pp. 485-497.

28. Stevens, B. (2008). Corporate Ethical Codes: Effective Instruments for Influencing Behavior, Journal of Business Ethics, 78, 601-609.

29. UNESCO, (2011). Financing Education in Sub-Saharan Africa. Meeting the Challenges of Expansion, Equity and Quality, Montreal: UNESCO Institute for Statistics.

30. UNESCO, (2014). Research and Experimental Development, Institute for Statistics.

31. Zahra, S., Hayton, J., \& Salvato, C. (2004). "Entrepreneurship in family vs non-family firms: a resource-based analysis of the effect of organizational culture", Entrepreneurship Theory \& Practice, Vol. 28 No. 4, pp. 363-381. 